1 Climate Information Services for Adaptation: What does it mean to Know the Context?

2

3

4

5

6 Zack Guido*, Institute of the Environment, University of Arizona, 1064 E. Lowell Street, Tucson,

7 Arizona 85721-0137, USA; zguido@email.arizona.edu; 520-626-0252

8 Chris Knudson, Institute of the Environment, University of Arizona, 1064 E. Lowell Street, Tucson,

9 Arizona 85721-0137, USA

10 Donovan Campbell, Department of Geography and Geology, University of the West Indies (Mona),

11 Kingston, Jamaica

12 Jhannel Tomlinson, Department of Geography and Geology, University of the West Indies (Mona),

13 Kingston, Jamaica

14

15

16

17 Declarations of interest: none

18

19

20

21

22 * Corresponding author: ORCID: $0000-0002-4817-606 \mathrm{X}$ 


\section{Climate Information Services for Adaptation: What does it mean to Know the Context?}

Abstract

27 Climate information services (CIS) can reduce climate vulnerability by enhancing information access,

28 knowledge exchanges, and networks. Central to CIS is the need to understand the social and

29 environmental context in which information is used. While researchers have identified many influential

30 dimensions, there lacks rigorous analysis of all the dimensions salient to a CIS case study as well as a

31 model to help CIS implementers design and evolve their CIS in its course. This research addresses these

32 gaps by analyzing a CIS we developed for coffee farmers in Jamaica that introduced new weather and

33 climate information in workshops, text messages, and interviews. We identify nine dimensions related to

34 the information providers, users, and their union, and we show how each influenced the design and

35 evolution of our CIS. We further show their dynamic relations in an analytical model. We argue that the

36 context is emergent, requiring flexible CIS, and that assessing the providers is as important as a focus on

37 the users, which is often the emphasis in CIS scholarship. This study is a demonstration of how varied

38 contextual dimensions affect the design, implementation, and use of a CIS, while also providing empirical

39 detail about a coffee farming and climate context.

\section{Key Words}

52 CIS, climate information services, coffee, climate adaptation, smallholder farming, seasonal climate

53 forecasts 


\section{Introduction}

55 Climate and weather variability can have harmful and beneficial effects on nearly all sectors of society.

56 Scholars and development professionals have therefore focused on developing the ability of individuals to

57 manage climate risk. At the individual level, activities that can help improve the management of climate

58 risk include access to information, knowledge exchanges, and social networks (Smit \& Wandel, 2006).

59 Climate information services (CIS) have recently emerged as a new area of research and practice that

60 integrate these three elements (Brasseur \& Gallardo, 2016; Dessai, Hulme, Lempert, \& Pielke, 2009;

61 World Meteorological Organization, 2016).

63 CIS develop, translate, and disseminate climate-related and other relevant information for decision-

64 makers by engaging stakeholders, utilizing appropriate access mechanisms, and responding to user needs

65 (Brasseur \& Gallardo, 2016; World Meteorological Organization, 2011). CIS have thus become a

66 comprehensive approach for using technical weather and climate information to reduce vulnerability and

67 develop resilience (Carr \& Onzere, 2017). National governments and large donors and science

68 consortiums like the World Bank, CGIAR, and the World Meteorological Organization have invested

69 heavily in programs that improve the use of climate information (Vaughan \& Dessai, 2014). In 2014

70 alone, more than US\$24B was spent on CIS globally, close to the amount spent on weather services

71 (Georgeson, Maslin, \& Poessinouw, 2017)

73 An emerging tenet in the literature on CIS is to "know the context;" that is, information about the climate

74 becomes more usable when created or tailored with an understanding of the decision-maker's local social

75 and environmental context (Lemos, Kirchhoff, \& Ramprasad, 2012). This point has been emphasized in

76 numerous ways (e.g. Kirchhoff et al., 2013; Lemos et al., 2012; Moser, 2010; Vaughan and Dessai, 2014;

77 von Storch et al., 2011). Brugger et al. (2015) asserted that scientists must know how and why decisions

78 are made in order to provide actionable information, while Dilling and Lemos (2011: 684) stated "that

79 many of the constraints and limitations of [climate forecast] use originate in the lack of a broader

80 understanding of the decision-making environments." It has become clear from this work that the use- or

81 not-of climate information depends on each unique context.

82

83 In this analysis, we present a critical explication of a CIS the authors developed and implemented in

84 Jamaica with coffee industry representatives and the national meteorological service, with routine

85 feedback from smallholder coffee farmers. This CIS focused on improving understanding and access to

86 weather and seasonal climate forecasts (SCF) through participatory workshops, text messages, and

87 individual interviewers. The research goal was to understand the contextual dimensions that guided the 
activities implemented, while coffee industry stakeholders' goals were to enhance their communication with farmers and help them build resilience to weather and climate variability.

Our analysis is founded on a learning-by-doing approach common to a nascent field like CIS where both scholars and practitioners build theory and practice in tandem (Bremer et al., 2019; Harjanne, 2017). As

93 part of this theorization process, we argue that the context should be broadly construed, encompassing the

94 conditions and characteristics of information users, the information providers and their union.

We make this argument by identifying and describing nine distinct dimensions of the context, where each influenced the CIS design, evolution, and efficacy. While each of the dimensions has been the focus of studies on climate adaptation, SCF, and communication, we document how they all combine in a dynamic way to affect a CIS. In so doing, we show the importance of designing flexible CIS that can accommodate changes in the users as well as growth in the providers' knowledge of the contexts. Beyond these conclusions, our analysis is a rare glimpse at the multiple dimensions of implementing a CIS. At the same time as providing empirical detail about Blue Mountain (BM) coffee farming, this analysis serves as a CIS analytical model for both practitioners and scholars that can help information providers make informed decisions about project design, content, and evaluation, among other elements that influence a CIS's efficacy. While CIS involve multiple actors who each benefit from knowing the context, CIS often have an operational component where information comes from somewhere and is stewarded by someone. As such, the responsibility of knowing the context falls heavily on the provider, particularly in situations where information is newly introduced.

This article proceeds first with a review of connecting scientific information to different audiences. In section 3, we describe the research setting: a brief introduction to coffee farming in Jamaica, our CIS, and

112 our methods of analysis. In section 4, we detail how the nine dimensions influenced our CIS. And in

113 section 5, we bring these dimensions together in a dynamic analytical model that can help implementers

114 understand the context, the important dimensions to observe, and why it is important to reflect on the 115 users' and providers' contexts.

2. Literature Review: Contextual Dimensions of Climate Information Use

118 The use of climate and weather information across different sectoral, cultural, and economic settings has

119 stimulated a growing body of research from scholars of climate adaptation, policy, and science

120 communication (e.g. Mase and Prokopy, 2014; Moser, 2014, 2010; Moser and Dilling, 2011; Tall et al.,

121 2018; Vaughan and Dessai, 2014). This work has revealed numerous barriers and effective strategies that 
122 are related to local conditions. In this section, we summarize the topics that are routinely discussed, with a

123 particular focus on the developing world context. For convenience, we adopt two common terms in the

124 CIS literature, while recognizing they are imperfect (Vaughan, Buja, Kruczkiewicz, \& Goddard, 2016):

125 "Information users" ("users," for short) are those who receive and apply climate and weather information

126 and "providers" are those who transform raw data into more refined forms.

128 Perhaps the most referenced contextual qualities relate to users' perceptions of salience, credibility, and 129 legitimacy (SCL) (Cash et al., 2003; Hansen, Mason, Sun, \& Tall, 2011; Patt \& Gwata, 2002). Salience

130 refers to the relevance of the information to an expressed need and is driven both by information supply

131 and demand. Salience is a function of comprehension and access. If farmers are unable to understand a

132 forecast, they will use it incorrectly or not at all. Likewise, if information is provided via web portals, it

133 will reach only those with Internet connections. Access to climate information in many developing

134 countries is highly uneven, and can be quite low (Vaughan, Hansen, Roudier, Watkiss, \& Carr, 2017).

Perceptions of credibility relate to the scientific adequacy of the information being used (Cash et al., 2003) and the credentials and rhetorical skills of information providers (Moser, 2010). Certain messengers like respected community leaders can provide the psychological signals that instill confidence in the information (Moser, 2010). Moreover, interpersonal skills like humility and respect for different perspectives are effective at bridging disciplinary and cultural divides (Brugger et al., 2015). They not only influence perceptions of credibility but also legitimacy. Legitimacy relates to how faithful

142 stakeholders' values and beliefs are represented, the degree to which the process is perceived as unbiased, 143 and the quality of stakeholder participation in the knowledge production process.

145 The effects of SCL are profound. They can influence the desire to act, who is empowered or not (White et 146 al., 2010), and who benefits (Patt \& Gwata, 2002). Roncoli et al. (2002) showed that West African 147 farmers use traditional knowledge and scientific forecasts in complementary and divergent ways. They 148 concluded that attending to the differences and similarities between traditional knowledge and western 149 science can help introduce technical forecasts in culturally appropriate and locally relevant ways (Roncoli 150 et al., 2002). Additionally, Carr and Onzere (2017) showed that agrometeorological advisories in Mali fit 151 better with male household responsibilities than with female responsibilities, while Patt and Gwata (2002) 152 stated that the goals of national level policy-makers may be at odds with those of individual actors. In the 153 latter case, recommendations can be beneficial on average but harmful to specific people. In this sense, 154 the messenger does not simply convey information, but also brokers power. 
156 Language, and the meanings ascribed to information, present an additional contextual influence. Weather

157 and climate forecasts are often presented in mathematical formats that some users find difficult (Stern \&

158 Easterling, 1999) while others less so (Luseno, McPeak, Barrett, Little, \& Gebru, 2003). Pre-existing

159 training and experience with probabilities, for example, can influence use (Grothmann \& Patt, 2005).

160 Moreover, farmers can use forecasts for cognitive and affective ends (Roncoli et al., 2009), in addition to

161 the instrumental outcomes that often frame the goals of CIS.

162

163 As a response to a need to establish SCL, climate information delivery has trended towards more 164 engagement (Mase \& Prokopy, 2014). Projects have therefore been designed to be iterative (Meadow,

165 Guido, Crimmins, \& McLeod, 2016). The form of engagement, however, is tied to the available project

166 resources, a part of the context that impacts what and how CIS are implemented (Meadow et al., 2015).

167 Furthermore, engagement requires a unique set of interpersonal skills that are often not included in

168 climate science training (Brugger et al., 2015). In these respects, the context includes the providers,

169 making insights from communication relevant.

Studies on risk communication have shown that when information users became experts in their own

172 right, and are treated as such, their perceptions of credibility and legitimacy are greater (Patt \& Gwata,

173 2002). In a review of climate change communication, Moser (2010) highlighted that the efficacy of

174 communication is influenced by a common understanding of the goals of the communication as well as of

175 the modes of communication. Whereas the goals influence both the design of, and the resource demands

176 on, the communication effort, the modes shape what can be said, the means by which it can be conveyed,

177 and the opportunities for social learning. Participatory workshops, as one mode of communication, have

178 shown promise in increasing the use of SCF (Patt, Suarez, \& Gwata, 2005). In fact, many recently

179 implemented efforts deploy participatory forms of engagement, some following farmer field school

180 approaches (Dayamba et al., 2018). Yet, both the mode and goals can be shaped as much by the resources

181 available and the priorities of funders as by the users' needs.

183 Where present, knowledge brokers and boundary organizations have helped engender SCL,

184 comprehension, access, and facilitated engagement. Brokers and boundary organizations play

185 intermediary roles, preforming activities like translating technical information (Guido, Hill, Crimmins, \&

186 Ferguson, 2013), facilitating knowledge exchanges, and selecting key participants (Buizer, Jacobs, \&

187 Cash, 2016; Clark et al., 2016). The adoption of remote engagement via information communication

188 technologies has helped overcome time and resource constraints characteristic of these activities (Kettle

$189 \&$ Trainor, 2015). However, intermediaries and resources are lacking in many developing countries where 
national agricultural extension is often hampered by these limitations (Olazabal, Chiabai, Foudi, \&

191 Neumann, 2018). And while NGOs and multilateral development projects have provided support, that are

192 often incongruent with local needs (Harvey, Jones, Cochrane, \& Singh, 2019). Nonetheless, the presence

193 and capacity of intermediary actors make up an institutional context that helps shape what and how CIS

194 are implemented.

195

\section{Research Setting}

\section{3.1. Coffee Cultivation in the Blue Mountains}

198 In Jamaica, coffee is grown in several regions but is concentrated in the relatively higher elevation area

199 around the BMs (Figure 1). There, farmers grow the coffea arabica variety Typica. At the time of the last

200 census in 2004, there were approximately 7,000 registered coffee growers in the BMs. The vast majority

201 of these farmers operate farms smaller than five acres.

While the livelihoods of the small-scale farmers in the BMs are diversified, coffee is the preferred income source. BM coffee is world renowned and receives some of the highest prices on the global market (ICO, 2018). Yet, coffee is highly sensitive to social and environmental conditions for several reasons. First, coffee in the BMs is predominantly rain-fed, and periodic droughts reduce quality and quantity. Second, volatile market conditions impinge on the ability of small-scale farmers to manage their farms (ICO, 2013). In times of reduced income, BM farmers respond by using fewer agricultural inputs, leaving coffee trees more susceptible to hazards like plant diseases and droughts (Author, 2018). This occurred in 2013 when a widespread coffee leaf rust (CLR) outbreak affected BM farmers and later between 2013 and

2112016 during a severe drought. These shocks made it difficult for coffee farmers to earn a viable income

212 (Author, 2018). Consequently, the Coffee Industry Board (CIB) 1 — the statutory body that regulates and

213 promotes Jamaican coffee — has sought ways to improve climate resilience.

215 In collaboration with CIB, we spent several years working to understand opportunities for climate and

216 weather information to help farmers manage their farms and in particular CLR (Author, 2018). We

217 concluded that better access to weather forecasts and SCF, which were unknown to the vast majority of

218 smallholder farmers despite being disseminated by the Meteorological Service of Jamaica (MSJ), could

219 enhance coffee production. However, this required reducing barriers to accessing and understanding the

\footnotetext{
${ }^{1}$ In 2018, CIB became part of the newly formed Jamaica Agricultural Commodities Regulatory Authority (JACRA), which includes regulatory boards for several agricultural commodities including coffee. We use CIB throughout this analysis because CIB existed through the majority of our project and to be clear that our results refer to the coffee function of JACRA.
} 
220 information. The findings provided the impetus for the development of the CIS we report on in this

221 article.

\subsection{CIS: Participatory Workshops, Routine Text Messages, and Interviews}

224 The CIS consisted of three distinct activities beginning in June 2017 and ending in August 2018:

225 participatory workshops, text messages, and interviews. This phase was a pilot with CIB expressing

226 interest to continue some activities if cost was justified. Upon the pilot's completion, CIB was seeking

227 additional funds but had not obtained them.

229 The users of the CIS were primarily smallholder farmers and the providers were represented by the 230 research team, MSJ, CIB, and the Inter-American Institute for Cooperation on Agriculture (IICA).

231 Together, we convened three sets of workshops in June and August 2017 and January 2018. We began

232 sending text messages after the first workshop until August 2018. The interviews occurred between

233 September 2017 and February 2018.

The workshops engaged nine communities clustered in six locations (Figure 1). We convened a total of 17 workshops - three in each of five rural locations and two in a sixth location where we canceled the third workshop due to dangerous travel conditions caused by persistent rain. Each workshop lasted approximately four hours. A total of 406 farmers participated in at least one workshop, of which 142 (35\%) were female. A member of CIB worked with community leaders to invite participants.

We designed the workshops drawing on a growing body of participatory CIS activities for agriculture, mainly implemented in the developing world (Chandra, Dargusch, McNamara, Caspe, \& Dalabajan, 2017; Dorward, Clarkson, \& Stern, 2015; Hansen, 2015; Mwanga, Kisanga, \& Dinh, 2017; Roncoli,

244 Orlove, Kabugo, \& Waiswa, 2011; Srinivasan, Rafisura, \& Subbiah, 2011; Winarto, Stigter, Prahara, \&

245 Anantasari, 2011). The workshops facilitated conversations with the farmers about climate and the role of 246 weather and climate information in their coffee management. Table 1 displays a workshop agenda from 247 the first workshop series to provide detail about our engagement with the farmers during these events.

Following the first round of workshops, the MSJ began sending weather and climate information via text messages to the participants who volunteered for the pilot project. Each week on Monday and Thursday the MSJ sent a weather forecast for the next 3-day and 4-day periods, respectively. An example of the

252 weather forecast text is: "Thu: Partly cloudy with showers. Fri: Mainly fair and hot. Sat-Sun: Fair 253 mornings, isolated afternoon showers." The MSJ also sent a seasonal precipitation forecast once a month 
254 when the forecast was publicly released and also occasionally included a seasonal temperature forecast.

255 An example of this seasonal precipitation forecast is: "Seasonal rainfall forecast: total rainfall for Aug,

256 Sept, Oct is more likely to be below normal (50\%) than normal (30\%) or above normal (20\%)." We sent

257 text messages to 372 unique farmers and a total of 42,979 texts messages were sent. We also conducted

258 phone interviews with 166 farmers which included opportunities for farmers and researchers to discuss

259 the text messages, workshops, and farming conditions. We provide more details on the interviews in the

260 next section.

\section{3.3. Methods of Analysis}

263 During the workshops, two members of the author team recorded group discussions using participant

264 observations. We complemented our observations with semi-structured phone interviews of the

265 participants beginning after the second workshop. Each month we interviewed a random selection of

266 approximately 20 participants from the pool of farmers who participated in at least one of the first two

267 workshops (referred to as Random Group hereafter; $\mathrm{n}=104$ ). For the random group, we asked questions

268 predominantly about the meaning and use of the information. Additionally, each month we also

269 interviewed an unchanging set of 12 farmers, two from each of the six communities (referred to as

270 Tracked Group hereafter; $n=62$ ). We were, however, not always successful in contacting each farmer

271 every month. We tracked this group to understand how perceptions and use of climate information

272 changed over time. All interviews lasted about 20 minutes. A member of the author team completed all

273166 interviews. We conducted content analysis on participant observations and interviews to identify key

274 themes, and we provide descriptive statistics of the random group interviews as well as representative

275 quotations from the both the tracked and random group interviews.

277 4. Nine Dimensions of the Users and Providers Contexts

278 We identified nine contextual dimensions that were all influential in our CIS. They fall into the three

279 categories of the end users, the providers, and their union. In this section, we elaborate on the reasons

280 each dimension is important for a CIS - drawing on the literatures of science communication, CIS and

281 climate adaptation - and how each dimension manifested in our CIS. Table 2 provides their overview.

282 While there are interrelations between these dimensions, it is instructive to look first at each individually.

283 We then discuss their relationships in Section 5.

\subsection{The Context of the Information Users}




\subsubsection{Main Concerns}

287 In order for a CIS to be useful it must be salient and address a problem (Cash et al., 2003). In science 288 communication, effective translation utilizes frames that resonate with a user's core beliefs and values, 289 and thus provides meaning to ideas (Nisbet \& Mooney, 2007). In a CIS, therefore, understanding what is 290 of concern will enable information to be fit for purpose and to be received more openly. The latter is 291 particularly important when new information is introduced.

293 In our case, the coffee farmers experience multiple persistent and overlapping stressors (Author, 2018)

294 that have affected coffee production (Figure 2). In 2008, for example, the global economic recession

295 lowered the prices farmers received for their crop, thus limiting their purchase of fertilizers. By 2012, the

296 coffee trees' weakened state from inadequate plant nutrition and care likely contributed to the first

297 widespread outbreak of CLR in Jamaica. Low plant nutrition has been associated with CLR elsewhere

298 (e.g. Avelino et al., 2015).

300 Given this, we framed the CIS as a tool to help farmers decide when to apply inputs. The first

301 workshops drew connections between weather and climate and management decisions (Table 1).

302 However, by the second workshop series, coffee's farm-gate price fell by half. When we asked

303 farmers to describe their main challenge to their coffee production, about $95 \%$ stated the low

304 coffee prices (87 of 92 respondents in the Random Group; 12 farmers did not answer).

By the second round of workshops, the price shock influenced the workshop dynamics. At the workshops, our CIB partner fielded many questions about price, often from frustrated participants. The price drop also appeared to limit the importance of the weather and climate forecasts. One farmer stated during dialogs about forecast use: "If farmers had sufficient inputs, they would have been able to spray their fields instead of watching their berries spoil and their crops destroyed" (workshop, August 2017). This change caused us to reframe the next set of workshops, focusing on how weather and climate forecasts

314 This example illustrates two points. First, the main concerns can change, thereby necessitating dynamic

315 framing. A constant framing would have jeopardized the attention and trust of the farmers. Second, 316 framing goes beyond capturing attention. It also requires linking abstract information to concrete actions.

317 We therefore discussed in the workshops how forecasts can improve the timing of input applications in 318 order to make their limited resources more efficient. 


\subsubsection{Audience Characteristics}

Knowing the audience is a key, if not defining, characteristic of effective communication. Diverse audiences may require different communication modes, have different concerns, and desire different information (Carr \& Onzere, 2017; Dilling \& Lemos, 2011). By matching the information to the audience, information providers can design appropriate frames and goals, and send useful messages (Vaughan \& Dessai, 2014).

In our case, it took close inspection to reveal six distinctions at the farmer-level that influence the use of climate information for decisions on agricultural inputs (Table 3). The influence of elevation is one example. At higher elevations, the cherries on trees ripen at the time when CLR begins to spread. However, farmers are prohibited from spraying fungicides at this time due to chemical residue limits on harvested cherries. Other farmers not harvesting, however, can treat the disease. Another example of farmer-level differences that affected the utility and efficacy of the information was awareness of proper CLR treatment. Farmers who were unaware that CLR-infected leaves are best treated by spraying the underside of the leaves would not reap all benefits from a forecast that helped them decide when to spray. (See Table 3 for other examples).

The farmer differences were therefore key in two decisions we made. First, we included only weather and climate information in the text messages and excluded recommendations. Advice for applying chemicals, for example, could have benefited some farmers, while possibly harming others. Second, because forecast information without agricultural knowledge would yield more limited results, we designed the workshops to explicitly link the forecasts to farming practices. Furthermore, because farmers had no prior experience

\subsubsection{User Decisions}

345 Scholars argue that a focus on the decision-making context is needed to guide the creation, translation,

346 and provision of climate information (Goddard, 2016). In this respect, information can be fit for a purpose 347 (Lemos et al., 2012). Knowing when a person needs to act — say, to plant a crop variety for an upcoming 348 season — can help information providers deliver the right information at the right time.

349 In our workshops, we discussed the timing of on-farm activities. Farmers plant seedlings in the spring and

350 fall and fertilize and spray chemicals during specific months. Within this seasonal calendar, the days of 351 these activities are conditioned by the actual or anticipated weather, making weather forecasts a useful 352 tool. One farmer stated: "Based on the message that came yesterday, I decided to spray some coffee as the 
weather would be good for it. Over the weekend, [the text message] said there would have been rains in

354 the afternoon, so in the morning I decided to burn some grass" (Random Group interview, September

355 2017).

356 Similarly, the SCF could inform longer-term planning. Farmers, for example, could anticipate needing

357 fungicides if the spring rains were expected to be above-normal. While the workshop identified

358 opportunities for SCF use, the interviews revealed however that farmers were unable to use them for two

359 principal reasons. Most prominently, the fall in coffee price had restricted their ability to plan. Many

360 farmers could not pay for both labor to harvest the cherries and fertilizers. Consequently, farmers chose to

361 hire labor so that cherries would not rot, thereby prioritizing present concerns over future production. The

362 second principal reason relates to the comprehension of the SCF, which we discuss in the next section.

363 In our team's discussions prior to the workshop, we considered only sending SCF based on the project's

364 focus of seasonal timescales and because fewer texts would minimize communication costs. However,

365 with a context unfavorable for SCF use, and because farmers had immediate uses for weather forecasts,

366 we decided to send both weather and SCF information. We also recognized that SCF may become useful

367 at a future time. Providing weather forecasts that had immediate value helped the farmers experiment with

368 and gain trust in SCF even if they did not use them in an instrumental way. The tradeoff, however, was an

369 increase in cost from more frequent communication that reduced the duration of the pilot texting.

\subsubsection{Meanings of Information Communicated}

372 Language barriers are a common challenge in communicating climate information. Non-scientists and

373 scientists often interpret technical language differently (Bruine de Bruin \& Bostrom, 2013). Risk

374 communication specialists have therefore stressed the importance of identifying where providers and

375 users differ in their understanding of scientific information (Taylor, Dessai, \& de Bruin, 2015). This is

376 particularly important for the communication of SCFs, which are often presented as shifts in the

377 probability of tercile categories, a level of abstraction that presents challenges for many users (Stern and

378 Easterling, 1999).

380 In our case, we were concerned that farmers would not understand the language of both weather forecasts

381 and SCF and that text messages did not allow for clarification. We therefore focused each workshop on

382 discussing the meaning of the forecasts and testing the language used in the messages. We further

383 conducted interviews for additional feedback. 
We structured the workshops in two ways to facilitate learning. First, we discussed weather forecasts before the SCF because most farmers had experience using the former. Many farmers were aware of forecast uncertainty because weather forecasts in Jamaica are issued for the entire island even though local conditions vary substantially. We therefore learned that many farmers understood probabilities and preferred their inclusion in the texts. Second, the workshops focused on how SCFs convey the likelihood of total rainfall and on the meaning of the following terms used by MSJ to describe total rainfall: "above normal", "below normal", and "normal." Creating a common vocabulary is important because farmers differed in their understanding of the SCF. One farmer stated that normal meant "isolated rainfall" whereas another stated "normal rains in the past are when farmers could go into the fields and get work done" (workshop, August 2017). We also learned through interviews that farmers imbued meaning into the forecasts that extended beyond the technical definition, including assigning notions of frequency and intensity of rain, while also struggling to articulate a meaning of the SCF (Figure 3).

We therefore made several decisions based on farmers' interpretation of the forecast language. First, we tailored the SCF texts to include probabilities. Second, because farmers interpreted the forecasts in different ways, with a majority unable to state a meaning, each workshop focused on discussing the exact information conveyed in the SCF. Moreover, we learned from our interviews that the farmers' ability to state the correct meaning of an SCF did not substantially improve over time as might be suspected with greater exposure. Therefore, upon completion of the pilot project, we recommended more engagement with the farmers to develop a common lexicon and increase understanding.

\subsection{The Context of the Information Providers}

\section{4.2.1 Capacity to Engage with Users}

408 In CIS scholarship, analysis of the context is often focused on the users (e.g. Goddard, 2016), while that of the providers is emphasized less. This overlooks the role of the providers in engendering trust and bridging divides (e.g. Moser, 2010). Furthermore, participatory activities are often used to connect users and providers, rendering a high importance to facilitation and listening skills and assumptions of the audience. Because providers play as important a role on the efficacy of CIS as users, the capacity of the providers is therefore a relevant dimension to critique. In our case, the context of the providers was important in two ways. First, the small-scale farmers feel neglected and marginalized by the more powerful members in the supply chain. Many farmers voiced comments such as, "As the small farmer we do not feel connected to the coffee system. We feel as though we are alone and no one is really there to advocate for us and speak on our behalf" (Random Group 
419 interview, February 2018). This statement reflects a general sense that coffee institutional representatives,

420 along with other organizations, supports only the larger farmers' interests. At times, the farmers were

421 visibly frustrated with our team.

422

423 At other workshops, we were perceived to have power and authority. One farmer stated: "You are here

424 talking about how the farmer can take care of the coffee, but not talking to the buyers how to take care of

425 the farmers" (Workshop, August 2017). This farmer viewed our role as brokering better relationships

426 between the small-scale and coffee buyers. It was not surprising, then, that some of the workshops

427 became a rare opportunity for the farmers to voice their grievances. In one August workshop, the farmers

428 questioned a member of CIB about the price fall for nearly half of the workshop. In this way, the

429 composition of our team influenced what we discussed. Moreover, this example shows that providers

430 need to recognize at the outset their position of power with respect to the users.

432 A second way our context influenced the CIS was the result of our sometimes false assumptions of the

433 farming reality. This played out during the third workshop series in a demonstration to illustrate the value

434 of having knowledge of the future climate. We gave farmers hypothetical money and asked them to

435 choose an investment strategy based on a forecast. After the demonstration, one farmer asked us, "What if

436 you did a more real to life thing and say you don't have anything to invest?" A member of our team

437 responded, "You must have something," to which the farmer rhetorically asked, "Can I come to you for

438 it? " In this case, our preconceptions were that most farmers had the ability to purchase at least some

439 inputs and what they lacked was information about the future. This assumption led us to use valuable time

440 at the workshops to present an unrealistic, and perhaps misguided activity. It also ran the risk of alienating

441 our audience. It further demonstrates the importance of stating assumptions and questioning them.

$443 \quad$ 4.2.2 Resources

444 CIS that are user-driven necessarily involve collaboration with decision-makers (Brasseur \& Gallardo,

445 2016). In this way, CIS are a transdisciplinary process (Schuck-Zöller, Brinkmann, \& Rödder, 2018) that

446 have unique engagement challenges. Developing working relationships and then sustaining collaboration

447 among different partners are resource-intensive processes that are amplified by the multifaceted and

448 changing context. The dynamic context requires flexible project management and team composition.

450 Coffee farming, like most occupations, is embedded in complex management systems. In order for

451 climate and weather information to be introduced in ways that are attuned to this complexity, we needed

452 to first develop relationships with CIB and MSJ. Prior to implementing the CIS, we spent several years 
working with these organizations to understand opportunities for climate and weather information

454 (Author 2018). This process helped develop trust among all participants, and provided the necessary time

455 to develop roles. For example, the MSJ wanted to send the text messages due to their mandate as the

456 national authority for weather and climate information. The IICA and CIB developed the agronomic

457 aspects of the workshops. And the university team helped provide coordination and data analysis that

458 shaped project design.

460 Yet, we were not always able to meet the resource demands. For example, our initial information

461 dissemination plan included CIB leading the development of a seasonal bulletin to be shared by CIB and

462 Jamaica's Rural Agricultural Development Authority (RADA). However, CIB and RADA's other

463 commitments prevented the development of the bulletins.

465 Moreover, we considered other models of engagement such as farmer field schools and the Participatory 466 Integrated Climate Services for Agriculture approach (Braun, Jiggins, Röling, van den Berg, \& Snijders, 467 2006; Dorward et al., 2015). However, the communities' remoteness made it difficult to hold workshops 468 in more than six locations. Furthermore, a combination of the high cost of workshops and busy farmers, 469 led us to convene three half-day events instead of more numerous events characteristic of field school 470 models. We also provided a travel stipend and lunch to compensate for attendance. Despite this, only $9 \%$ 471 of all participants attended all three workshops. We thus concluded that we needed to better incentivize 472 participants to attend all three workshops but also surmised that even with full attendance we would have 473 needed more than three workshops.

\subsubsection{Project Design}

476 Projects designed to be responsive to learning and to reflect critically on how research builds adaptive 477 capacity to climate risks are important activities in generating useful knowledge for planning, policy, and 478 implementation (Preston, Rickards, Fünfgeld, \& Keenan, 2015). Projects that are reflective recognize that 479 users and providers lack relevant facts, the context is dynamic, and that all actors need to continually 480 bridge knowledge divides (Lemos \& Morehouse, 2005). From the provider's perspective, an iterative 481 approach allows assumptions to be reframed, conclusions to be redrawn, and activities to be modified482 adjustments likely to be a constant during the project.

484 Reflexivity is both a summative and formative process. It is formative in the sense that it is unrealistic for 485 providers to have the full picture at the outset. For example, prior to the workshops, our team had not 486 discussed the weather and climate information with the farmers. At the first workshop, we therefore were 
unsure if farmers would understand probabilities. Only after our interactions did we decide that the

488 widespread use of weather forecasts was a foundation on which to use probabilities in the SCF. While this

489 is only one example, in each of the eight other sections we highlight other changes that occurred as the

490 project evolved. They argue for a malleable approach able to adjust as understanding builds and the

491 external context shifts.

493 Project design should also have a summative assessment in order to reveal final outcomes and identify

494 process challenges and best practices. What works and why remains key knowledge gaps in CIS

495 (Vaughan \& Dessai, 2014). In our case, we collected household baseline data in 2016 to compare with a

496 final future assessment. While we do not report this comparison in this analysis, pre- and post-

497 intervention assessments are often used to evaluate instrumental effects: a relative increase in yields

498 among users of climate information, for example. Our pre-assessment was geared mostly towards

499 instrumental-type outcomes. However, our interactions and observations during the workshops strongly

500 suggest that assessments should consider a broad set of information use outcomes that include cognition,

501 affect, social inclusion, and other measures of subjective wellbeing. The importance of inclusion was

502 stressed by one farmer who stated: "Attending the seminar here and giving our cell numbers now make us

503 a part of the system. We are in the know, we are privileged" (workshop, August 2017). Psycho-social

504 aspects as well as social and human capitals are key metrics in resilience and vulnerability, but less

505 emphasized in evaluations of CIS (e.g. Tall et al., 2018).

\subsection{Union of the Users and Providers Contexts}

\subsubsection{Communication modes}

509 Many aspects of the context affect the mode of communication and who delivers it, which in turn effect

510 the impact of the information conveyed (Moser, 2010). In the BM, coffee farmers live in remote

511 communities and have limited access to technical support services. The CIB, which provides the principal

512 extension support for the BM, has only three extension officers for the approximately 3,600 BM farmers.

513 The remoteness of the communities and their limited interactions suggest existing extension channels

514 based on face-to-face interactions are insufficient for frequent communication. Moreover, although the

515 MSJ has provided SCF on their website since 2012, nearly all farmers who participated in the pilot had

516 not seen one before our workshops. The elements that affect communication are thus a combination of the

517 users' and providers' contexts.

519 For our CIS, we relied on two communication modes: text messaging and group and one-on-one

520 interactions. Text messages enabled frequent communication to a large number of farmers at an 
521 inexpensive cost. Additionally, texts were suitable because the BM farmers have a high literacy rate and

522 there is widespread cell phone coverage and usage in the BMs. MSJ became the communicator of the text

523 messages due to existing institutional responsibilities. But while this effort fit its mandate, MSJ has

524 limited human and financial resources, and how to sustain the texts beyond the pilot program was an

525 underlying concern. We embarked with the knowledge that only if the study made a compelling case for

526 future funding would we seek a future solution. However, sustainability was never resolved in this pilot

527 phase.

528

529 Any mode of communication, however, presents tradeoffs: a 160-character text, for example, is passive

530 and one-way, but it is also relatively inexpensive. Passive forms can be effective communication modes

531 (e.g. Carr and Onzere, 2017), but in-person conversations that facilitate inquiry may also be needed and

532 are often more effective at developing understanding and informing actions (Lee, Lee, \& Scnumann,

533 David, 2002).

In designing the CIS, we recognized that most farmers would be unaware of SCF and all the ways weather and climate information could inform coffee management. Text messaging alone was therefore an inadequate method to meet our goals. We included the workshops to share information and facilitate discussion, which would make the content in the texts more accessible. To gauge how the information was received, during the second and third workshops and interviews we asked farmers about specific text messages we had sent and we tailored the communications accordingly. In this way, the workshops were testbeds to refine the information in the messages.

\subsubsection{Goal Alignment}

544 From a provider's perspective, CIS are often initiated to improve existing management decisions and 545 generate an instrumental effect. Yet, the ability to influence behaviors - particularly at the individual 546 level — is often predicated on economic development (Eakin, Lemos, \& Nelson, 2014). Therefore, in cases 547 where economic capacity is low, instrumental outcomes may be aspirational, at least in the short term. On 548 the other hand, users can derive other benefits. In our case, the initial reason for developing the CIS did 549 not ultimately align with the benefits the farmers received. We had to adjust our goals and expectations.

As we prepared for the first workshop, the goal of the CIS was to inform the best time to apply fungicides 552 and fertilizers. Based on results from previous work (Author, 2018), we found that farmers perceive plant 553 nutrition and disease control as critical for good yields. However, the high costs of inputs prevent many 
farmers from using them at recommended levels. In this resource-limited environment, wasted inputs are irreplaceable and the importance of proper allocation and efficiency are heightened.

However, because of the dramatic fall in coffee price, many farmers could not purchase inputs at all. The information we were providing, therefore, could not inform resource allocation as intended. One farmer summarized this, stating: "I would like to do some fertilizing but I am unsure as to when this will be done as I am awaiting some money to purchase the inputs" (Tracked Group interview, October 2017). In fact, after six months of interviews, we saw only slight evidence that farmers used the weather forecasts to

562 inform decisions and only one farmer stated he had used a climate forecast in this way.

Yet, the messages and workshops had other, potentially more significant benefits. For one, many farmers

565 liked having the texts easily accessible on their phones. Additionally, the workshops and messages

566 conveyed a sense of importance to a group who perceive themselves to be neglected and excluded from

567 industry-level decision-making. As previously noted, one farmer expressed his gratitude for inclusion:

568 "Attending the seminar here and giving our cell numbers now make us a part of the system. We are in the know, we are privileged" (workshop, August 2017). And another farmer expressed both surprise and appreciation for the workshops, stating: "You all are from the CIB? They never come here." (workshop, January 2018).

Although we did not document much use of the information in coffee management, we observed social benefits. The ones we have mentioned - convenience and inclusion - were observed along with others such as awareness and edification. While these may not contribute directly or immediately to behavior change, they could prepare for instrumental uses. This is particularly salient for project evaluations. Measuring outcomes cast only in terms of informing decisions may miss important benefits. In our preassessment, we did not measure psycho-social effects and under-emphasized cognition and elements of social capital. We therefore missed an opportunity to evaluate the effects of the CIS on these components.

\section{Discussion}

583 knowledge of this context grew, and how both fostered changes in our CIS activities. We did not 584 anticipate many of these changes, in part because they are dynamic and interrelated. We show their 585 relationships and direction of influence in Figure 4. While this model does not depict all the possible 586 links, we show those that were the most consequential during our CIS. 
In section 5.1 below, we elaborate on two pathways that we experienced, which can be traced as a set of nodes connected by arrows in Figure 4. The first traces the project at its early implementation and design phase, while the second follows links that occurred at a later project stage. We then reflect on insights this model reveals.

\subsection{The Dynamics of the Context}

594 The first pathway begins with the initial conceptualization of our CIS, where we hypothesized that the 5952013 outbreak of CLR was causing hardship for the BM coffee farmers given their Audience

596 Characteristics. (The capitalized and italicized terms are our contextual dimensions in Figure 4). Prior to 597 the CIS, our baseline survey in 2016 conveyed that CLR's impact on production was one of the Main

598 Concerns across the BM coffee industry. Consequently, we oriented our activities to inform Decisions on 599 when to apply treatment and plant nutrition and to provide expectation of the seasonal rainfall; the latter 600 would provide clues about the potential severity of the disease in future months. The Main Concerns thus 601 dictated what Decisions we targeted. The Decisions then influenced the Project Design by compelling the 602 inclusion of both weather and climate information, two different timescales that reinforced the effect of 603 the other. The Project Design, in turn, affected both the Resources required and the Communication 604 Mode. Taking the Resources first, our transdisciplinary team needed to include expertise in agriculture 605 extension, disease management, meteorology, and climate so that we had the necessary Capacity to 606 Engage with the farmers on the issue of linking the forecasts to farming activities. The Project Design, 607 the Resources of our project team, and the Audience Characteristics all influenced the Communication 608 Mode. The fact that cell coverage was widespread was one reason text messages were viable.

609 Furthermore, the MSJ needed to disseminate the information in the text based on its mandate as the 610 Jamaica's weather and climate authority. However, texts alone were insufficient to overcome the users' 611 knowledge gaps. The CIS needed to combine active and passive Communication Modes. Moreover, 612 because CLR is easily transported from one farm to another by wind and laborers harvesting the coffee, 613 all farmers need to manage CLR. Thus, our Project Design was geared to reach as many farmers as 614 possible, further emphasizing a need for an economically efficient Communication Mode. The aim was 615 for Goal Alignment between the providers and the farmers: reduced coffee losses due to CLR.

617 The aphorism "Know the Context" has become ubiquitous within CIS because of the many dimensions 618 that each influence the what, when, how, and outcome of an intervention. The context, however, is not 619 static. The constant changes of each dimension require responsive, flexible CIS. We experienced this 620 before our second set of workshops when the farmers began to directly experience the impact of a large 621 fall in the farmgate price of coffee. Because the farmers principally earn their income from coffee, the 
622 farmers' apprehension about the price replaced CLR as their Main Concern. Moreover, because many

623 farmers struggle to purchase agricultural inputs even under profitable circumstances, the price decline

624 rendered purchasing inputs nearly impossible. The farmers' Characteristics amplified by the charge in the

625 price caused the Goal of our CIS - to inform input usage - to be unrealistic in the short term. Thus, we

626 recalibrated expectations, while we also reframed and modified our activities within our Communication

627 Modes to focus on mitigating the price decline. As a response, we therefore designed the third workshop

628 with an economic module to show the value-added of continual plant maintenance under different

629 scenarios of investment.

630

\subsection{A model to Know the Context}

632 The nine dimensions in Figure 4 serve as an analytical model. First, at a higher order, we find that the 633 context is larger than that of the users. The context also encompasses providers and the intersection of 634 both the users and providers. In this way, CIS providers are critically reflective of themselves and take 635 seriously the notion of challenging their own assumptions and skills. Furthermore, while all CIS has a 636 starting point, the constant flux of all the dimensions causes the context to be emergent. In fact, CIS 637 implicitly attempt to change the context, and successful ones will. "Know the Context" is therefore a call 638 for CIS to be flexible and responsive.

640 At the dimensional level, Figure 4 also shows that the audience characteristics dimension links to more 641 dimensions than any other. Often, the focus in CIS is on the users' decisions (Dilling \& Lemos, 2011;

642 Goddard, 2016). The decisions, however, are a function of users' characteristics. Therefore,

643 understanding the audience reveals why those decisions are made, when, and how, among other important

644 details. In this way, there are certain dimensions that are more likely to change than others based on their

645 number of connections and their position downstream of other dimensions. Communication modes, for

646 example, is downstream of four dimensions spanning each category of the users, providers, and their

647 union. Dimensions like communication modes are therefore apt to change frequently, requiring more

648 constant monitoring and adjustments to remain fit for purpose. In reflecting upon each dimension and

649 their totality, providers can thereby continually adjust their activities.

\section{Conclusion}

652 CIS are ways to reduce climate vulnerability and build resilience. To be most effective in these goals, 653 scholars and practitioners suggest that CIS must fit the context in which they are used. As we have 654 shown, the context is varied, dynamic, and complex. How, then, can one know the context? 
From an analysis of our own CIS, we identified nine dimensions that shaped the design and implementation of our activities and assembled them into an analytical model that helps us understand the context. Taken together, we suggest that these nine dimensions constitute the context that can both be actively managed and serve as a guide in creating more effective CIS (Table 2). Instead of being faced with a plethora of diverse facts about a CIS intervention, the providers can use this model as a way to systematically identify the essential contextual dimensions, comprehend their interrelations, and adjust the project over time to accommodate change.

664 Our study offers several important insights about knowing the context. First, the context is dynamic and 665 emergent. It is dynamic because each dimension links to others, and changes in one can have a rippling

666 effect. It is emergent because the context is ever-changing. These properties argue for continued

667 engagement so that the CIS can reflect on itself and be able to evolve as the context dictates.

669 Second, while it has been long recognized that each context is multi-dimensional and unique, analyses of

670 the context typically focus on the end user. However, solely focusing on the users produces an incomplete analysis because users only exist in a context shared with the providers. The providers play important roles in project design and engagement, among others, that interact with the users. It is therefore important for CIS to emphasize reflection on the providers' context as much as the users'.

While CIS will be specific to a particular people and place, we suggest that our model also applies to many other situations in which climate information is brought to bear on local issues in a participatory way. While the relative importance of each dimension is context dependent-collaborations between state water agencies in the U.S. will be very different than working with Jamaican coffee farmers - in most cases, assessing the users, the providers, and their union will inform the design, implementation, and use of CIS. Indeed, these are the outcomes of knowing the context.

\section{Acknowledgements}

683 We are indebted to the farmers who shared their ideas and time, often in lieu of tending their farms. We

684 also wholeheartedly thank Gusland McCook and Noel Richards from JACRA; Glenroy Brown and

685 Ronald Moody from MSJ; Elizabeth Johnson from the Inter-American Institute for Cooperation on

686 Agriculture; and Teddy Allen, Malgosia Madajewicz, and Ashley Curtis from International Research

687 Institute for Climate and Society. This research was funded by the NOAA (grant NA13OAR4310184)

688 with contributions from USAID under the International Research and Applications Project. 


\section{References}

691 Avelino, J., Cristancho, M., Georgiou, S., Imbach, P., Aguilar, L., Bornemann, G., ... Morales, C. (2015).

692 The coffee rust crises in Colombia and Central America (2008-2013): impacts, plausible causes and proposed solutions. Food Security, 7(2), 303-321. https://doi.org/10.1007/s12571-015-0446-9

694

695

696

Brasseur, G. P., \& Gallardo, L. (2016). Climate services: Lessons learned and future prospects. Earth's Future, 4(3), 79-89. https://doi.org/10.1002/2015EF000338

Braun, A., Jiggins, J., Röling, N., van den Berg, H., \& Snijders, P. (2006). A Global Survey and Review of Farmer Field School Experiences. Report prepared for the International Livestock Research Institute (ILRI). Endelea, Wageningen, The Nethrelands. Retrieved from https://www.researchgate.net/profile/J_Jiggins/publication/228343459_A_Global_Survey_and_Revi ew_of_Farmer_Field_School_Experiences/links/0046353bd1e61ab7f7000000/A-Global-Surveyand-Review-of-Farmer-Field-School-Experiences.pdf

Bremer, S., Wardekker, A., Dessai, S., Sobolowski, S., Slaattelid, R., \& van der Sluijs, J. (2019). Toward a multi-faceted conception of co-production of climate services. Climate Services, 13, 42-50. https://doi.org/10.1016/J.CLISER.2019.01.003

Brugger, J., Meadow, A., \& Horangic, A. (2015). Lessons from First Generation Climate Science Integrators. Bulletin of the American Meteorological Society. https://doi.org/10.1175/BAMS-D-1400289.1

Bruine de Bruin, W., \& Bostrom, A. (2013). Assessing what to address in science communication. Proceedings of the National Academy of Sciences of the United States of America, 110 Suppl(Supplement 3), 14062-14068. https://doi.org/10.1073/pnas.1212729110

Buizer, J., Jacobs, K., \& Cash, D. (2016). Making short-term climate forecasts useful: Linking science and action. Proceedings of the National Academy of Sciences of the United States of America, 113(17), 4597-4602. https://doi.org/10.1073/pnas.0900518107

Carr, E. R., \& Onzere, S. N. (2017). Really effective (for 15\% of the men): Lessons in understanding and addressing user needs in climate services from Mali. Climate Risk Management. https://doi.org/10.1016/J.CRM.2017.03.002

Cash, D. W., Clark, W. C., Alcock, F., Dickson, N. M., Eckley, N., Guston, D. H., .. Mitchell, R. B. (2003). Knowledge Systems for Sustainable Development. Proceedings of the National Academy of 

http://www.jstor.org/stable/3139884

721 Chandra, A., Dargusch, P., McNamara, K. E., Caspe, A. M., \& Dalabajan, D. (2017). A Study of Climate722 Smart Farming Practices and Climate-resiliency Field Schools in Mindanao, the Philippines. World Development, 98, 214-230. https://doi.org/https://doi.org/10.1016/j.worlddev.2017.04.028

724 Clark, W. C., Tomich, T. P., van Noordwijk, M., Guston, D., Catacutan, D., Dickson, N. M., \& McNie, E. 725 (2016). Boundary work for sustainable development: Natural resource management at the

Dessai, S., Hulme, M., Lempert, R., \& Pielke, R. J. (2009). Climate prediction: a limit to adaptation? In Consultative Group on International Agricultural Research (CGIAR). Proceedings of the National Academy of Sciences, 113(17), 4615-4622. https://doi.org/10.1073/pnas.0900231108

Dayamba, D. S., Ky-Dembele, C., Bayala, J., Dorward, P., Clarkson, G., Sanogo, D., ... Zougmore, R. (2018). Assessment of the use of Participatory Integrated Climate Services for Agriculture (PICSA) approach by farmers to manage climate risk in Mali and Senegal. Climate Services. https://doi.org/10.1016/j.cliser.2018.07.003

W. N. Adger, I. Lorenzoni, \& K. L. OBrien (Eds.), Adapting to Climate Change (pp. 64-78). Cambridge: Cambridge University Press. https://doi.org/10.1017/CBO9780511596667.006

Dilling, L., \& Lemos, M. C. (2011). Creating usable science: Opportunities and constraints for climate knowledge use and their implications for science policy. Global Environmental Change, 21(2), 680689. https://doi.org/10.1016/j.gloenvcha.2010.11.006

Dorward, P., Clarkson, G., \& Stern, R. (2015). Participatory Integrated Climate Services for Agriculture (PICSA): Field Manual. Walker Institute, University of Reading. Retrieved from https://ccafs.cgiar.org/publications/participatory-integrated-climate-services-agriculture-picsa-fieldmanual\#.W-ihrRNKjOQ

Eakin, H. C., Lemos, M. C., \& Nelson, D. R. (2014). Differentiating capacities as a means to sustainable climate change adaptation. Global Environmental Change, 27, 1-8. https://doi.org/10.1016/J.GLOENVCHA.2014.04.013

Georgeson, L., Maslin, M., \& Poessinouw, M. (2017). Global disparity in the supply of commercial weather and climate information services. Science Advances, 3(5), e1602632. https://doi.org/10.1126/sciadv.1602632 
Goddard, L. (2016). From science to service. Science, 353(6306), 1366-1367. https://doi.org/10.1126/science.aag3087

Grothmann, T., \& Patt, A. (2005). Adaptive capacity and human cognition: The process of individual adaptation to climate change. Global Environmental Change, 15(3), 199-213. https://doi.org/10.1016/j.gloenvcha.2005.01.002

Guido, Z., Finan, T., Rhiney, K., Madajewicz, M., Rountree, V., Johnson, E., \& McCook, G. (2018). The stresses and dynamics of smallholder coffee systems in Jamaica's Blue Mountains: a case for the potential role of climate services. Climatic Change, 147(1-2), 253-266. https://doi.org/10.1007/s10584-017-2125-7

Guido, Z., Hill, D., Crimmins, M., \& Ferguson, D. (2012). Informing Decisions with a Climate Synthesis Product: Implications for Regional Climate Services. Weather, Climate, and Society, 5(1), 83-92. https://doi.org/10.1175/wcas-d-12-00012.1

Hansen, J. (2015). Training workshop on communicating weather and climate information with farmers, Same, Tanzania, September 2013. CCAFS Workshop Report. Copenhagen, Denmark: CGIAR Research Program on Climate Change, Agriculture and Food Security (CCAFS). Retrieved from http://www.ccafs.cgiar.org.

Hansen, J. W., Mason, S. J., Sun, L., \& Tall, A. (2011). Review of seasonal climate forecasting for agriculture in sub-Saharan Africa. Experimental Agriculture. Cambridge University Press. https://doi.org/10.1017/S0014479710000876

Harjanne, A. (2017). Servitizing climate science-Institutional analysis of climate services discourse and its implications. Global Environmental Change, 46(Supplement C), 1-16. https://doi.org/https://doi.org/10.1016/j.gloenvcha.2017.06.008

Harvey, B., Jones, L., Cochrane, L., \& Singh, R. (2019). The evolving landscape of climate services in sub-Saharan Africa: What roles have NGOs played. Climatic Change, 1-18.

ICO. (2013). Report on the outbreak of coffee leaf rust in central America and action plan to combat the pest. London.

ICO. (2018). Historical Data on the Global Coffee Trade.

Kettle, N. P., \& Trainor, S. F. (2015). The role of remote engagement in supporting boundary chain 
networks across Alaska. Climate Risk Management, 9, 6-19. https://doi.org/10.1016/J.CRM.2015.06.006

Kirchhoff, C. J., Lemos, M. C., \& Dessai, S. (2013). Actionable Knowledge for Environmental Decision Making: Broadening the Usability of Climate Science. Annual Review of Environment and Resources, 38(1), 393-414. https://doi.org/doi:10.1146/annurev-environ-022112-112828

Lee, E.-J., Lee, Ji., \& Scnumann, David, W. (2002). The Influence of Communication Source and Mode on Consumer Adoption of Technological Innovations. Journal of Consumer Affairs, 36(1), 1-27. https://doi.org/10.1111/j.1745-6606.2002.tb00418.x

Lemos, M. C., Kirchhoff, C. J., \& Ramprasad, V. (2012, October 26). Narrowing the climate information usability gap. Nature Climate Change. Nature Publishing Group. https://doi.org/10.1038/nclimate1614

Lemos, M. C., \& Morehouse, B. J. (2005). The co-production of science and policy in integrated climate assessments. Global Environmental Change, 15(1), 57-68. https://doi.org/10.1016/J.GLOENVCHA.2004.09.004

Luseno, W. K., McPeak, J. G., Barrett, C. B., Little, P. D., \& Gebru, G. (2003). Assessing the value of climate forecast information for pastoralists: Evidence from Southern Ethiopia and Northern Kenya. World Development, 31(9), 1477-1494. https://doi.org/10.1016/S0305-750X(03)00113-X

Mase, A. S., \& Prokopy, L. S. (2014). Unrealized Potential: A Review of Perceptions and Use of Weather and Climate Information in Agricultural Decision Making. Weather, Climate, and Society, 6(1), 4761. https://doi.org/10.1175/WCAS-D-12-00062.1

Meadow, A., Ferguson, D., Guido, Z., Horangic, A., Owen, G., \& Wall, T. U. (2015). Moving toward the deliberate coproduction of climate science knowledge. Journals.Ametsoc.Org, 7(2), 179-191. https://doi.org/10.1175/WCAS-D-14-00050.1

Meadow, A. M., Guido, Z., Crimmins, M. A., \& McLeod, J. (2016). From principles to action: Applying the National Research Council's principles for effective decision support to the Federal Emergency Management Agency's watch office. Climate Services, 1, 12-23. https://doi.org/10.1016/j.cliser.2016.02.002

Moser, S. C. (2010). Communicating climate change: history, challenges, process and future directions. 
Wiley Interdisciplinary Reviews: Climate Change, 1(1), 31-53.

805

Moser, S. C. (2014). Communicating adaptation to climate change: the art and science of public engagement when climate change comes home. Wiley Interdisciplinary Reviews: Climate Change, 5(3), 337-358. https://doi.org/10.1002/wcc.276

Moser, S. C., \& Dilling, L. (2011). Communicating climate change: closing the science-action. In The Oxford handbook of climate change and society (pp. 161-174.). https://doi.org/10.1093/oxfordhb/9780199566600.003.0011

Mwanga, S., Kisanga, J., \& Dinh, D. (2017). Workshop report: Participatory Integrated Climate Services for Agriculture (PICSA) Intermediary Training, Dodoma, Tanzania. Copenhagen, Denmark: CGIAR Research Program on Climate Change, Agriculture and Food Security (CCAFS). Retrieved from http://www.ccafs.cgiar.org

Nisbet, M. C., \& Mooney, C. (2007). Science and Society: Framing Science. Science, 316(5821), 56-56. https://doi.org/10.1126/science. 1142030

Olazabal, M., Chiabai, A., Foudi, S., \& Neumann, M. B. (2018). Emergence of new knowledge for climate change adaptation. Environmental Science \& Policy, 83, 46-53. https://doi.org/10.1016/J.ENVSCI.2018.01.017

Patt, A., \& Gwata, C. (2002). Effective seasonal climate forecast applications: Examining constraints for subsistence farmers in Zimbabwe. Global Environmental Change, 12(3), 185-195. https://doi.org/10.1016/S0959-3780(02)00013-4

Patt, A., Suarez, P., \& Gwata, C. (2005). Effects of seasonal climate forecasts and participatory workshops among subsistence farmers in Zimbabwe. Proceedings of the National Academy of Sciences, 102(35), 12623-12628. https://doi.org/10.1073/pnas.0506125102

Preston, B. L., Rickards, L., Fünfgeld, H., \& Keenan, R. J. (2015, June 1). Toward reflexive climate adaptation research. Current Opinion in Environmental Sustainability. Elsevier. https://doi.org/10.1016/j.cosust.2015.05.002

Roncoli, C., Ingram, K., \& Kirshen, P. (2002). Reading the Rains: Local Knowledge and Rainfall Forecasting in Burkina Faso. Society \& Natural Resources, 15(5), 409-427. https://doi.org/10.1080/08941920252866774 
832 Roncoli, C., Jost, C., Kirshen, P., Sanon, M., Ingram, K., Woodin, M., .. Hoogenboom, G. (2009). From 833 accessing to assessing forecasts: an end-to-end study of participatory climate forecast dissemination 834 in Burkina Faso (West Africa). Climatic Change, 92(3-4), 433-460. https://doi.org/10.1007/s10584$835 \quad 008-9445-6$

836 Roncoli, C., Orlove, B. S., Kabugo, M. R., \& Waiswa, M. M. (2011). Cultural styles of participation in 837 farmers' discussions of seasonal climate forecasts in Uganda. Agriculture and Human Values, 28(1),

Smit, B., \& Wandel, J. (2006). Adaptation, adaptive capacity and vulnerability. Global Environmental 123-138. https://doi.org/10.1007/s10460-010-9257-y

Schuck-Zöller, S., Brinkmann, C., \& Rödder, S. (2018). Integrating Research and Practice in Emerging Climate Services-Lessons from Other Transdisciplinary Dialogues (pp. 105-118). Springer, Cham. https://doi.org/10.1007/978-3-319-74669-2_8

Srinivasan, G., Rafisura, K. M., \& Subbiah, A. R. (2011). Climate information requirements for community-level risk management and adaptation. Climate Research, 47(1-2), 5-12. https://doi.org/10.3354/cr00962

Stern, P. C., \& Easterling, W. E. (Eds.). (1999). Making Climate Forecasts Matter, Panel on the Human Dimensions of Seasonal-to-Interannual Climate Variability. Washington, D.C.: National Academies Press: Committee on the Human Dimensions of Global Change, National Research Council.

Tall, A., Coulibaly, J. Y., \& Diop, M. (2018, June 29). Do climate services make a difference? A review of evaluation methodologies and practices to assess the value of climate information services for farmers: Implications for Africa. Climate Services. https://doi.org/10.1016/j.cliser.2018.06.001

Taylor, A. L., Dessai, S., \& de Bruin, W. B. (2015). Communicating uncertainty in seasonal and interannual climate forecasts in Europe. Philosophical Transactions. Series A, Mathematical, Physical, and Engineering Sciences, 373(2055), 20140454. https://doi.org/10.1098/rsta.2014.0454

856 Vaughan, C., Buja, L., Kruczkiewicz, A., \& Goddard, L. (2016). Identifying research priorities to advance 857 climate services. Climate Services, 4, 65-74. https://doi.org/10.1016/J.CLISER.2016.11.004

858 Vaughan, C., \& Dessai, S. (2014). Climate services for society: origins, institutional arrangements, and 859 design elements for an evaluation framework. Wiley Interdisciplinary Reviews: Climate Change, 
Vaughan, C., Hansen, J., Roudier, P., Watkiss, P., \& Carr, E. (2017). Evaluating agricultural weather and climate services in Africa: Evidence, methods, and a learning agenda. Washington, D.C. Retrieved from https://www.climatelinks.org/resources/evaluating-agricultural-weather-and-climate-servicesafrica

von Storch, H., Meinke, I., Stehr, N., Ratter, B., Krauss, W., Pielke Jr, R., ... Weisse, R. (2011). Regional climate services illustrated with experiences from Northern Europe. Zeitschrift Für Umweltpolitik Und Umweltrecht, 34(1), 1-16.

White, D. D., Wutich, A., Larson, K. L., Gober, P., Lant, T., \& Senneville, C. (2010). Credibility, salience, and legitimacy of boundary objects: water managers' assessment of a simulation model in an immersive decision theater. Science and Public Policy, 37(3), 219-232. https://doi.org/10.3152/030234210X497726

Winarto, Y. T., Stigter, K., Prahara, H., \& Anantasari, E. and K. (2011). Collaborating on establishing an agro-meteorological learning situation among farmers in Java. Anthropological Forum, 21(2), 175197.

World Meteorological Organization. (2011). Climate Knowledge for Action: A Global Framework for Climate Services--Empowering the Most Vulnerable (WMO-No. 10). The Report of the High-level Taskforce for the Global Framework for Climate Services. Geneva: World Meterological Organization.

World Meteorological Organization. (2016). Climate Services for Supporting Climate Change Adaptation: Supplement to the Technical Guidelines for The National Adaptation Plan Process. Geneva, Switzerland: World Meteorological Organization. Retrieved from https://library.wmo.int/pmb_ged/wmo_1170_en.pdf 


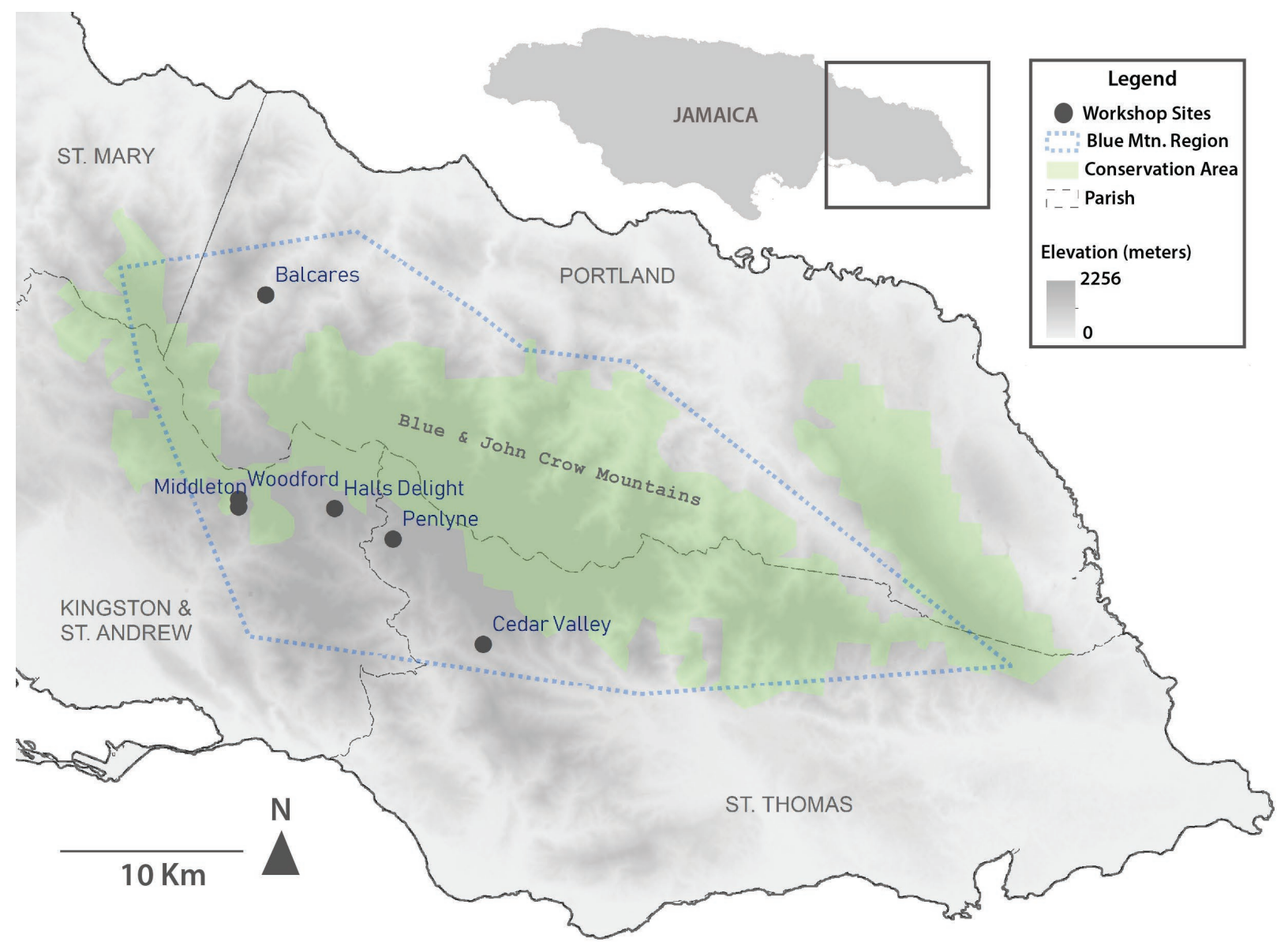

888 Figure 1. Map of the Blue Mountains coffee growing region and the workshop locations. Coffee

889 produced within the Blue Mountain coffee region is protected under the Blue Mountain Coffee Brand (the

890 boundary is approximate and was obtained from CIB). 


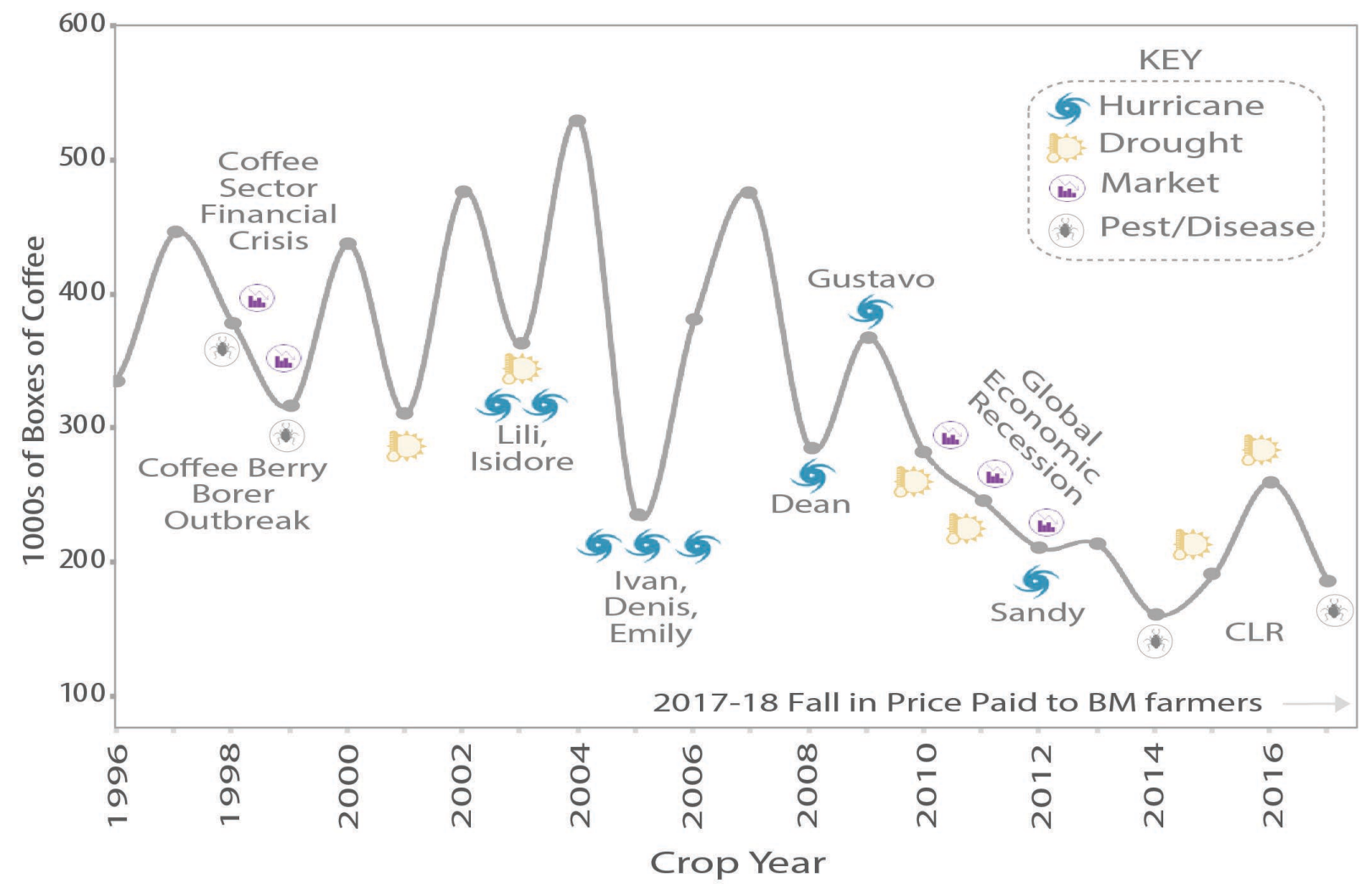

893 Figure 2. Timeline of notable stresses and shocks affecting coffee production in the BMs. Data for the

894 number of boxes produced (in thousands) in the BMs during each agricultural year (August 1 to July 31).

895 Data is from the CIB. Each data point corresponds to the June year (e.g. data plotted in 2016 represents

896 August 1, 2015 - July 31, 2016). One box of raw cherries weights about $27 \mathrm{kgs}$. The stresses and shocks 897 were identified in consultation with CIB and from Author 2018. CLR refers to coffee leaf rust. 


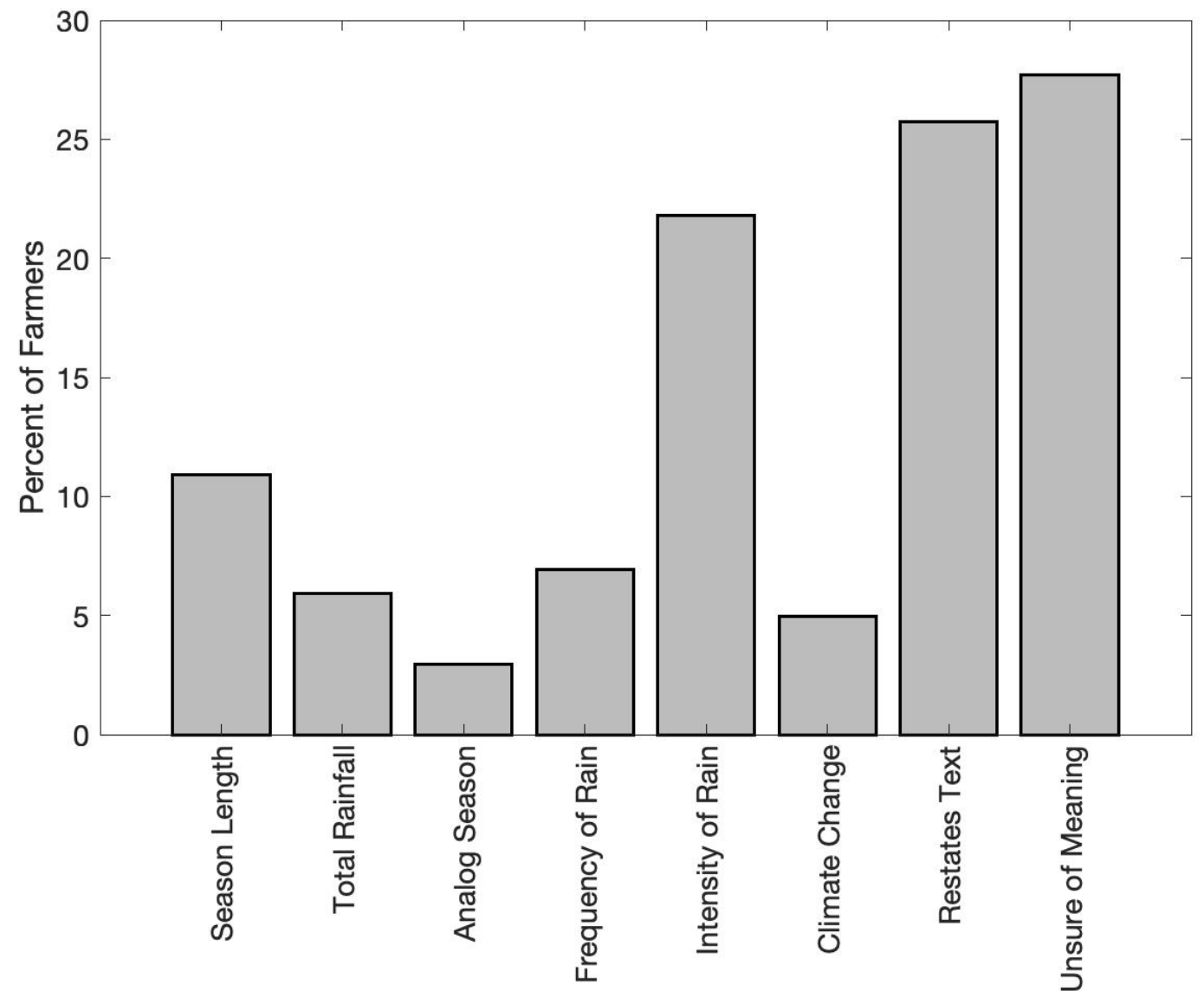

900 Figure 3. Different meanings ascribed to the SCF. Data is from the interviews we conducted with the 901 randomly selected farmers. Sample size is $101 ; 3$ farmers did not respond to this question. 

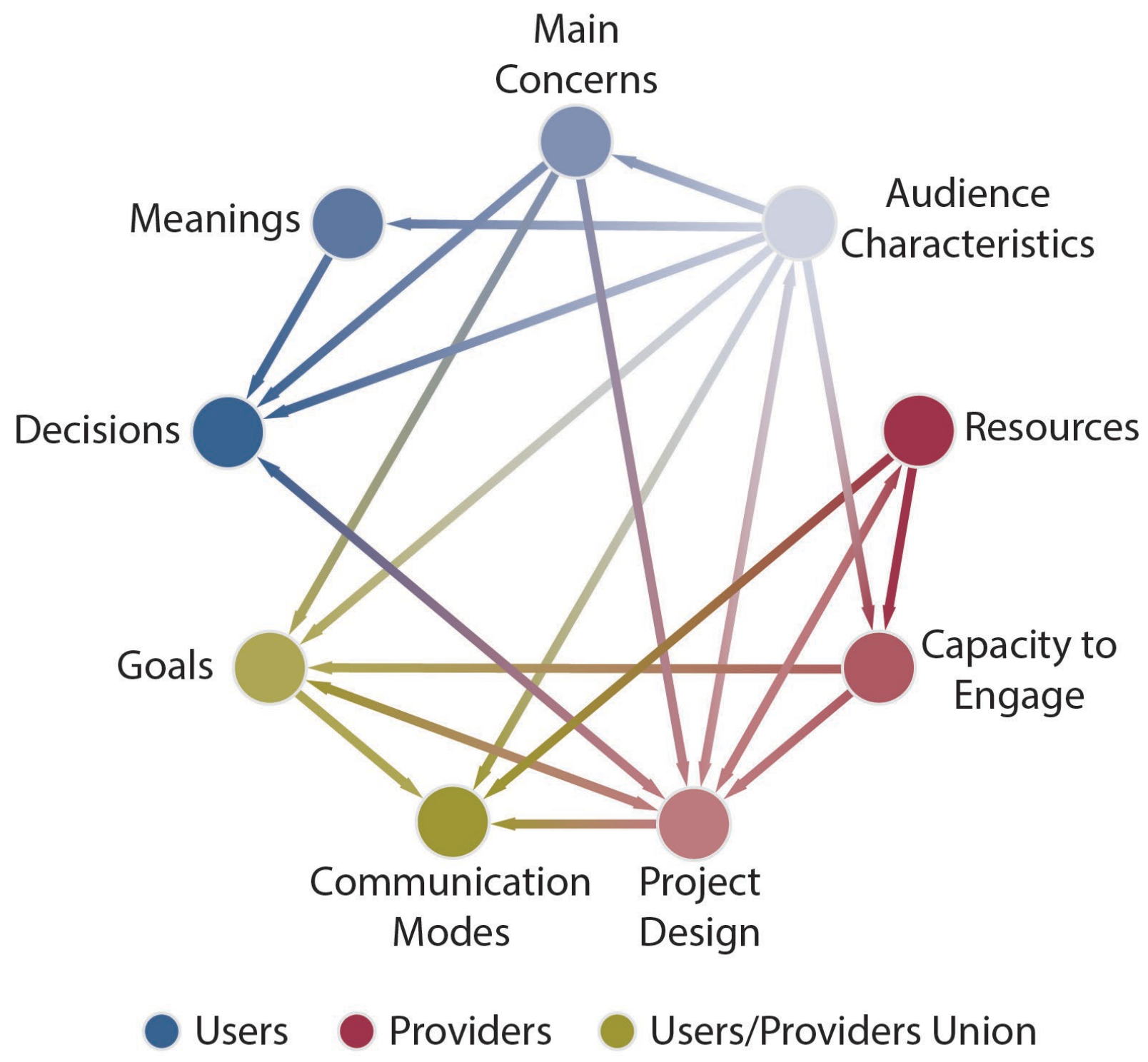

904 Figure 4. Model for developing an understanding of the context by monitoring and analyzing nine

905 dimensions that pertain to the users, providers, and the intersection of the two. The more prominent links

906 between the dimensions are noted, with the arrows depicting the directionality of influence. 
910 Table 1. Agenda for the first workshops in June 2017.

\begin{tabular}{|c|c|}
\hline $20 \mathrm{mins}$ & $\begin{array}{l}\text { Introduction to Workshop } \\
\text { Have an opening prayer, introduce project team, discuss project initiative and } \\
\text { goals, and present the day's agenda. }\end{array}$ \\
\hline $60 \mathrm{mins}$ & $\begin{array}{l}\text { Develop Calendar of Climate and Weather Conditions \& Coffee } \\
\text { Management Activities } \\
\text { Facilitate group discussion to develop a crop-climate-management calendar, } \\
\text { focusing on the coffee plant lifecycle, the lifecycle of coffee leaf rust, how } \\
\text { weather and climate conditions affect coffee and CLR, and how weather and } \\
\text { climate influence coffee management practices. }\end{array}$ \\
\hline $60 \mathrm{mins}$ & $\begin{array}{l}\text { Discussion of Weather and Climate Forecasts } \\
\text { Facilitate a discussion on the reasons why some people have and have not used } \\
\text { weather and climate information, how weather and climate information are } \\
\text { similar and different to each other, and some fundamental characteristics of } \\
\text { weather and climate information. }\end{array}$ \\
\hline 60 mins & $\begin{array}{l}\text { Lunch } \\
\text { Have a lunch catered by a local business. }\end{array}$ \\
\hline $60 \mathrm{mins}$ & $\begin{array}{l}\text { Weather and Climate Scenarios } \\
\text { Divide into small groups. Facilitate a discussion on how sample weather and } \\
\text { climate forecasts could influence farm management activities. }\end{array}$ \\
\hline $30 \mathrm{~min}$ & $\begin{array}{l}\text { Introduction to SMS system } \\
\text { Discuss the text messaging and the information that it will contain, with an } \\
\text { emphasis on its utility and limitations. }\end{array}$ \\
\hline 30 mins & $\begin{array}{l}\text { Next Steps } \\
\text { Summarize the day, solicit feedback on the workshop, discuss content of next } \\
\text { workshop two months later, open the floor for comments, thank participants, and } \\
\text { distribute a travel stipend to the farmers. }\end{array}$ \\
\hline
\end{tabular}


920 Table 2. The nine contextual dimensions of the context and their influence on the CIS.

\begin{tabular}{|c|c|c|}
\hline Category & Dimension & Influence on the CIS \\
\hline \multirow{4}{*}{ Users } & Main concerns & $\begin{array}{l}\text { The degree to which a CIS is seen as addressing salient } \\
\text { concerns influences opportunities, trust, and use of the service. } \\
\text { Main concerns, however, can change rapidly. }\end{array}$ \\
\hline & $\begin{array}{l}\text { Audience } \\
\text { characteristics }\end{array}$ & $\begin{array}{l}\text { Users are diverse. A person's experiences, perceptions, and } \\
\text { knowledge, among others, shape his or her understanding and } \\
\text { use of information. They also provide guidance for tailoring the } \\
\text { service. }\end{array}$ \\
\hline & User decisions & $\begin{array}{l}\text { The decisions farmers make help define opportunities and } \\
\text { barriers, while also providing direction for the form of the } \\
\text { service provided. }\end{array}$ \\
\hline & $\begin{array}{l}\text { Meanings of } \\
\text { information } \\
\text { communicated }\end{array}$ & $\begin{array}{l}\text { Technical language may be interpreted differently than } \\
\text { intended, and can lead to misinterpretations and } \\
\text { misapplications. }\end{array}$ \\
\hline \multirow{3}{*}{ Providers } & Resources & $\begin{array}{l}\text { Human and financial resources constrain the types and forms of } \\
\text { activities. }\end{array}$ \\
\hline & $\begin{array}{l}\text { Capacity to engage } \\
\text { with users }\end{array}$ & $\begin{array}{l}\text { The team composition, skillsets, and experiences influence the } \\
\text { types and forms of activities as well as the relationships with } \\
\text { the audience. } \\
\text { Construct teams with the right skill sets and an openness to } \\
\text { learn. }\end{array}$ \\
\hline & Project design & $\begin{array}{l}\text { The multidimensionality and dynamic nature of the entire } \\
\text { context requires updating efforts based on new learning of the } \\
\text { context. A flexible project design can lead to more favorable } \\
\text { outcomes. }\end{array}$ \\
\hline \multirow{2}{*}{$\begin{array}{l}\text { Union of } \\
\text { Users and } \\
\text { Providers }\end{array}$} & Communication modes & $\begin{array}{l}\text { The mechanism by which information is communicated } \\
\text { influences its accessibility, cost, and the content. There are } \\
\text { advantages and disadvantages in each mode. }\end{array}$ \\
\hline & Goal alignment & $\begin{array}{l}\text { The primary benefits may ultimately be different than expected. } \\
\text { Flexible goals may be more responsive to a wider set of } \\
\text { outcomes. }\end{array}$ \\
\hline
\end{tabular}


922 Table 3. Examples of audience characteristics that can influence a farmer's use of weather and climate 923 information.

\begin{tabular}{|c|c|}
\hline Element of difference & Influence on coffee and CIS use \\
\hline Elevation of farm & $\begin{array}{l}\text { Elevation influences coffee growth stages which, in turn, } \\
\text { determines if cherries ripen during spring rains and CLR } \\
\text { spreading. This timing influences if farmers can spray fungicides. }\end{array}$ \\
\hline $\begin{array}{l}\text { Knowledge of proper } \\
\text { management techniques }\end{array}$ & $\begin{array}{l}\text { Affects the efficacy of input usage. Information informing input } \\
\text { timing will be effective only if inputs are applied effectively. }\end{array}$ \\
\hline $\begin{array}{l}\text { Previous use of technical } \\
\text { weather and climate information }\end{array}$ & $\begin{array}{l}\text { Can affect the trust in the information and the comprehension of } \\
\text { probabilities. }\end{array}$ \\
\hline $\begin{array}{l}\text { Income and ownership of } \\
\text { productive tools }\end{array}$ & $\begin{array}{l}\text { Affects the ability to purchase inputs and tools like mechanical } \\
\text { sprayers. A CIS targeting decisions to apply inputs will be useful } \\
\text { only to those who can make these purchases. }\end{array}$ \\
\hline Contact with extension officers & $\begin{array}{l}\text { Affects access to farming information and weather and climate } \\
\text { information as well as trust in the messenger of the information. }\end{array}$ \\
\hline $\begin{array}{l}\text { Importance of coffee to the } \\
\text { livelihood }\end{array}$ & $\begin{array}{l}\text { Affects how much a farmer is willing to invest in their farm, and } \\
\text { therefore their willingness to use a CIS. }\end{array}$ \\
\hline
\end{tabular}

